\title{
The Small Group Context: \\ DESIGNATED District COURT JUDGES IN THE UNITEd States COURTS OF APPEALS
}

\author{
Paul M. Collins, Jr. \\ University of Houston \\ pmcollins@uh.edu \\ Wendy L. Martinek \\ Binghamton University \\ martinek@binghamton.edu
}

\begin{abstract}
Decision making in the United States Courts of Appeals occurs primarily in three-judge panels with rotating membership. A substantial proportion of court of appeals cases is decided by panels that include a judge who is not a regular court of appeals jurist but is, instead, a district court judge serving temporarily on the court of appeals bench. Taken together, these two traits mean that court of appeals decision making is often a function of small groups with temporary members. In this paper, we set out to examine whether designated district court judges behave differently than their court of appeals colleagues with whom they render decisions. And, in doing so, we suggest a profitable direction for theory building vis-à-vis judicial behavior. Our analysis of data contained in the United States Courts of Appeals Database indicates that the votes of judges on three-judge panels are influenced by the preferences of their fellow panelists and that variance in the ideological direction of votes cast is not systematically related to status as a designated district court judge, with such judges manifesting greater variance in their ideological decision making.
\end{abstract}

Paper prepared for delivery at the 2007 annual meeting of the Southern Political Science Association, New Orleans, LA, January 3-7, 2006. 


\section{Introduction}

The identity of a decision maker affects the decisions that are made. Scholars have amassed considerable evidence in support of this contention, whether the focus is on political elites or ordinary voters (e.g., Berelson, Lazarsfeld, and McPhee 1954; Campbell et al. 1960; Huckfeldt 1979; Mansbridge 1999). But decision makers do not act in a vacuum and scholars cognizant of this fact have directed our attention to the confluence of individual identities and group contexts that jointly result in political decisions (Caldeira, Clark, and Patterson 1993; Caldeira and Patterson 1987; Hare, Borgatta, and Bales 1965; Verba 1961). They argue, in short, that decisions are a function of both who decision makers are and with whom decision makers make their decisions. Law and courts scholars focused on strategic behavior explicitly recognize this sort of interdependence in conceptualizing the decision calculi of judges on collegial courts. ${ }^{1}$ Left largely unexplored, however, are the less strategic and more psychological aspects of the interaction of identities and context for appellate judges rendering collective decisions (Martinek 2006; but see Danelski 1989; Murphy 1966; Ulmer 1971; Walker 1973a, 1973b; Wrightsman 1999, 2006). In particular, members of collegial courts differ in the roles they play (both formally and informally defined) and those roles may have meaningful behavioral manifestations that are conditioned by the small group of which they are members.

Two particular features of decision making on the United States Courts of Appeals provide a unique opportunity to examine how the identities of judges and the small group context within which they operate can jointly shape behavior. First, the United States Courts of Appeals process the vast majority of their workload with the use of rotating three-judge panels (Cohen 2002, 72; Howard 1981, 188-192; Songer, Sheehan, and Haire 2000, 8). The chief judge of each circuit is responsible for constructing both the three-judge panels and the calendar of cases, though in practice the chief judge delegates these tasks to the court's administrative staff (Brown and Lee 2000; Feinberg 1984). The composition of each

\footnotetext{
${ }^{1}$ Hettinger et al. (2006) describe strategic behavior as follows: "[T]o achieve the outcome most compatible with their policy preferences, judges consider the impact of other judges' likely actions as well as their own. Depending on the preferences of other relevant actors and how those actors are likely to behave, a strategic judge might act differently than if his behavior was driven by attitudinal considerations alone" (74). Strategic accounts of judicial behavior are numerous in the context of the United States Supreme Court (e.g., Epstein and Knight 1998; Hammond, Bonneau, and Sheehan 2005; Maltzman, Spriggs, and Wahlbeck 2000), state courts of last resort (e.g., Hall 1992; Hall and Brace 1999; Langer 2002), and the United States Courts of Appeals (e.g., Cross and Tiller 1998; Van Winkle 1997; but see Hettinger, Lindquist, and Martinek 2004).
} 
panel is generally random ${ }^{2}$ and, with rare exception, the assignment of cases to particular panels is likewise random. ${ }^{3}$ Hence, court of appeals judges make most of their decisions in temporary small groups.

Second, a substantial proportion of court of appeals cases is decided by panels that include a judge who is not a regular court of appeals jurist but is, instead, a district court judge serving temporarily on the court of appeals bench. These district court judges, who are said to be serving by designation, occupy a unique position on three-judge circuit court panels. They are formally fungible with the regularly sitting court of appeals judges on the panel (Green and Atkins 1978). They enjoy formal decision-making equality with their fellow panel members, can and do author panel decisions, and possess the same prerogatives as the regularly sitting court of appeals judges with regard to the decision to concur or dissent. But, district court judges serving by designation remain district court judges, judges who, though familiar with federal law, normally serve in a very different capacity as a trial court judge than they do when called to (temporarily) serve as an appellate court judge. ${ }^{4}$ This has led a number of legal commentators to argue that, in fact, designated district court judges are not fully fungible with their court of appeals brethren (e.g., Brudney and Ditslear 2001; Cohen 2002; Saphire and Solimine 1995). ${ }^{5}$

Our immediate purpose in this paper is two-fold. First, we seek to exploit the U.S. Courts of Appeals Database to contribute new evidence with regard to the behavior of district court judges serving by designation, thereby helping to inform the continuing policy debate over their usage. Second, we attempt to advance our theoretical understanding of judicial decision making by applying a small group

\footnotetext{
${ }^{2}$ Though random assignment is not a function of statutory command, random assignment is the generally accepted norm and, indeed, is necessitated by circuit rules in some courts of appeals (Brown and Lee 2000; Solimine 1988). There is evidence to suggest, however, that random assignment has not always been the norm (Atkins and Zavoina 1974). And, charges of "panel stacking," such as in the case of the panel assigned to hear the recent Michigan University affirmative action cases, Gratz v. Bollinger, 539 U.S. 244, and Grutter v. Bollinger, 539 U.S. 306, continue to surface on occasion .

${ }^{3}$ The most notable exception is for cases that are closely related in substantive terms; e.g., cases that deal with the exact same issue of law. Such cases "may be assigned to the same panel in an effort to avoid unneeded repetition of effort and to avoid potential intracircuit conflicts" (Cohen 2002, 72). Cohen further notes that case assignments may be influenced by the desire to maximize equitable distribution of caseload, with attention paid to systematic differences in how time-consuming different kinds of cases are (2002, 72).

${ }^{4}$ As Carrington succinctly asserts, "The use of district judges does present a special problem with respect to its impact on the quality of review, since the qualities that make a good trial judge are somewhat different from those which make a good appellate judge" $(1969,565)$.

${ }^{5}$ Both courts of appeals and district court judges themselves recognize important differences in the roles they play and the skills needed to fulfill their respective roles (Cohen 2002, 192-199; Howard 1981, 134138).
} 
perspective to decision making on the United States Courts of Appeals. We begin by providing some necessary background about designated district court judges and synthesizing what scholars have uncovered thus far about their behavior.

\section{United States District Court Judges in the United States Courts of Appeals}

Pursuant to 28 U.S.C. $\S 292$ (1988), the chief judge of a circuit has the authority to designate a district court judge to serve in a temporary capacity as a court of appeals judge. ${ }^{6}$ This practice preceded statutory codification and has been a fact of judicial life in the courts of appeals from the time these courts were created under the Evarts Act of 1891 (Saphire and Solimine 1995, 360). Designated district court judges may serve temporarily on the courts of appeals but the service they provide is substantial. For example, from October of 1989 through September of 2004, any where from 250 to 375 district court judges provided service annually on the courts of appeals (Administrative Office of the United States Courts various years, Table V-2). ${ }^{7}$ Considered in terms of case participations ${ }^{8}$ instead of judges, in that same period, designated district court judges provided from 3,284 to 4,232 case participations per fiscal year (Administrative Office of the United States Courts various years, Table V-2). Though such service might be beneficial as an educational tool-facilitating the socialization of newly appointed district court judges (Note 1963, 878; Saphire and Solimine 1995, 361-362; Wasby 1980-81, 378)-the primary motivation for the circuits' reliance on designated district court judges is to facilitate the processing of the burgeoning workload faced by the courts of appeals (Green and Atkins 1978, 359-360; Saphire and Solimine1995, 362-363). ${ }^{9}$ The challenges to prompt adjudication facing the United States Courts of

\footnotetext{
${ }^{6}$ Under this statutory authority, chief judges can also seek the assistance of district court judges from other circuits but they can so serve only with the approval of the Chief Justice of the United States. A court of appeals judge from another circuit may also be "designated" to temporarily serve on a circuit other than his own home circuit but this is quite rare and, as with district court judges from outside of the circuit, such designation requires the approval of the Chief Justice of the United States.

${ }^{7}$ This includes service provided by active duty and retired district court judges. Most of these district court judges were active duty.

${ }^{8}$ Each judge participating in a case yields one case participation. Hence, a three-judge panel yields three case participations. Each en banc proceeding yields one case participation for each court of appeals judge in the circuit (assuming each participates in the en banc proceeding) or, in the case of the Court of Appeals for the Ninth Circuit, one case participation for each of the 15 judges who participates in the minien banc proceeding used in that circuit.

${ }^{9}$ In his account of the Court of Appeals for the Second Circuit under Chief Judge Learned Hand, Schick (1970) suggested one more reason for using designated judges: vacation planning. Schick quotes Congressman Frank Bow as arguing that the New York theatre season was correlated with California judges serving by designation in New York $(1970,78-19 \mathrm{fn}$. 12). Schick also reports that the chief judge of
} 
Appeals due to these burgeoning workloads is further exacerbated by the persistent vacancies on these courts, which have resulted from the contention attendant with the contemporary confirmation process (Citizens for Independent Courts 2000; Bell 2002; Scherer 2005).

The use of designated district court judges has been the subject of severe criticism. Some judges have suggested that, rather than ameliorate workload pressures, designated district court judges might actually exacerbate the workload facing court of appeals judges. They have the potential to do so because the regular court of appeals judges might feel compelled "to retain the important cases because they perceive that it would weaken the authority of an important rule if it were written by a visiting judge" (Cohen 2002, 196). Further, their lack of familiarity with circuit procedures may require visiting district court judges to impose on their panel colleagues for consultation and guidance (Cohen 2002, 197; Wasby 1980-1981). Finally, designated district court judges continue to have district court work of their own that requires their time and attention, forcing them to juggle the demands of both their district court and circuit court workloads $(2002,197)$.

Several legal scholars have also expressed reservations about the use of designated district court judges because they see the practice as having the potential to compromise the legitimacy of court of appeals decisions in the eyes of litigants, attorneys, and judges as well as the larger legal and political community (Alexander 1965; Note 1963, 879). Interviews of circuit judges in the United States Court of Appeals for the Ninth Circuit conducted by Wasby (1980-1981) in the late 1970s and more recently by Cohen $(2002,191-201)$ indicate that at least some of these judges do, in fact, worry that this practice will devalue the legitimacy of the courts of appeals.

Two of the most troubling criticisms of the reliance on designated district court judges are, first, that their use can compromise the quality of appellate review because such judges do not behave as independent members of appellate panels and, second, that this practice can compromise the consistency of the law because such judges act as wild cards in the panel decision process. ${ }^{10}$ Both

the Court of Appeals for the Third Circuit suggested that getting judges to serve by designation in Philadelphia was easier "when the Phillies had a better baseball team" $(1970,79)$.

${ }_{10}$ These dual criticism are like Scylla and Charybdis in that designated district court judges may be too deferential (and hence jeopardize the quality of appellate deliberations) or may not be deferential enough (and hence induce inconsistency in the law). 
claims, if substantiated by the empirical evidence, are especially disquieting because each relates to the essential functions of appellate courts.

Appellate courts use groups of judges, which "permits the collective decision-making essential to appellate adjudication without engendering excessive duplication of judicial effort" (Note 1963, 877-878). The operative principle is that appellate review requires the collective deliberation of more than one judge to avoid (or at least minimize) appellate error by either failing to correct a wayward trial court judge or, alternatively, reversing a trial court judge who was correct in his judgment (Drahozal 1998). To the extent that designated district court judges are deferential to the regular sitting, active duty court of appeals judges with whom they are deciding cases, that ideal of appellate deliberation is compromised:

District judges who serve for only short periods may view themselves and may be viewed as subordinate to their appellate counterparts. It may be difficult to set aside, even temporarily, the necessarily hierarchical nature of the relationship between the permanent and temporary judges. If so, the district judge may be deferential to his circuit counterparts and reluctant to vote differently in the form of concurring or dissenting opinions. Perhaps mindful that his own decisions are reviewed periodically, the district judge may be hesitant to depart from the vote of the two permanent circuit panel members (Saphire and Solimine 1995, 376).

And, indeed there is some evidence of this sort of deference on the part of district court judges in the extant literature. For example, both Brudney and Ditslear (2001) and Hettinger, Lindquist, and Martinek (2006, chapter 3) found designated district court judges less likely to dissent. Hettinger and her coauthors also found lower court reversal by the appellate panel to be less likely when the opinion author was a designated district court judge (2006, chapter 5). Further, some court of appeals judges themselves have indicated that district court judges serving by designation are inappropriately deferential. As one of the judges interviewed by Cohen observed, " $[\mathrm{A}]$ lot of them defer to the circuit judges. You have to have circuit judges working with circuit judges with the same power and the same power structure" (2002, 198).

Further, to achieve the social benefit of correcting error in the sense of deviations from "socially desirable decisions" (Shavell 2006, 2) ${ }^{11}$ appellate courts seek to promote stability and consistency in the law. Such consistency is requisite for citizens to effectively conform their behavior to the requirements of the established legal order. Consistency is also necessary for attorneys: "Uncertainty in doctrine, while

\footnotetext{
${ }^{11}$ See, also, Shavell (1995). Error correction can also take the form of inducing lower court compliance (Hettinger, Lindquist, and Martinek 2006, 21). The "error" in this sense of error correction is deviation by lower court judges from the preferred policy positions of superior court judges.
} 
undoubtedly of interest to academics and theoreticians, is an anathema to the practitioner whose sound counsel is dependent upon the stability that doctrinal stability affords" (Sullivan 2002, 810; see, also, Carrington 1969)..$^{12}$

District court judges serving by designation, however, have the potential to undermine consistency in the law: "Because a visitor [including a district court judge sitting by designation] is not a regular member of the court and does not sit on en banc proceedings, he introduces an element of instability on the panel on which he serves" (Carrington 1969, 565). A similar sentiment was voiced by one of the court of appeals judges interviewed by Cohen: "A district judge is supposed to make them [i.e., decisions] individually, and a court of appeals is supposed to make them collectively. That facilitates stability in the law, moderation, and predictability" $(2002,192)$. In sum, district court judges sitting by designation may threaten consistency in the law because they are temporary members, temporary members with different mindset who may be either less committed to consistency in circuit law or less equipped by virtue of experience to contribute to consistency in circuit law (Cohen 2002, 198).

There are, then, very real concerns about how the use of designated district court judges may affect the quality of the appellate process. The answer to the question of whether such judges manifest behavioral differences when compared to the regular sitting court of appeals judges has meaningful policy consequences and, for that reason alone, the question merits investigation. But, an examination of the behavior of designated district court judges can also contribute to theory building vis-à-vis judicial behavior.

\section{Designated District Court Judges and Theory Building}

For quite some time the preeminent theory of judicial decision making has been the attitudinal model (Segal and Spaeth 1993, 2002). In essence, the attitudinal model asserts that the votes of judges are the product of their ideological preferences: liberal judges vote liberally while conservative judges vote conservatively. To date, the most impressive evidence in support of the attitudinal model has been amassed by Segal and Spaeth $(1993,2002)$ for justices occupying the United States Supreme Court bench. But there is also a substantial body of research demonstrating the utility of the attitudinal model for

\footnotetext{
${ }^{12}$ The importance of consistency is reflected in the commitment of common law legal systems to the principle of stare decisis, the principle that like cases should be treated alike. Some legal scholars, however, urge a less rigid adherence to legal consistency as represented by stare decisis (Coons 1987; Peters 1996).
} 
understanding decision making on the United States Courts of Appeals (e.g., Goldman 1966, 1975; Songer and Haire 1992) and the United States District Courts (Carp and Rowland 1983; Rowland and Carp 1980, 1983; Ringquist and Emmert 1999; but see Rowland and Carp 1996) as well as state courts of last resort (e.g., Brace and Hall 1997; Hall and Brace 1996). There is also a small body of scholarship that supports the idea that the attitudinal model travels beyond the American context (e.g., Ostberg and Wetstein 2004).

Though reference to judicial attitudes and their influence is now de rigeur in the majority of current scholarship devoted to judicial decision making, several prominent scholars in the law and courts community see the emerging (emergent?) hegemon as the strategic model (e.g., Epstein and Knight 2000). ${ }^{13}$ While both the attitudinal and the strategic model start from the assumption that judges are policy-minded actors, the strategic model considers judges as forward-thinking individuals who take into account the interdependent nature of their decisions. The evidence in support of a strategic theory of judicial behavior is ubiquitous. With regard to the U.S. Supreme Court, perhaps the most compelling case in favor of the utility of the strategic model has been made in a recent series of articles and a book authored by Maltzman, Spriggs, and Wahlbeck (2000; Spriggs, Maltzman, and Wahlbeck 1999; Wahlbeck, Spriggs, and Maltzman 1998, 1999). ${ }^{14}$ The evidence regarding the strategic nature of decision making by state court of last resort judges is likewise abundant (Brace and Hall 1990, 1995; Hall 1992; Hall and Brace 1992, 1999; Langer 2002).

The evidence in the case of the United States Courts of Appeals, however, is neither as extensive nor as persuasive. Compare, for example, Van Winkle (1997) and Hettinger, Lindquist, and Martinek (2004) with regard to dissent as a strategic tool for signaling the circuit en banc. Further compare Cross and Tiller (1998) and Hettinger, Lindquist, and Martinek (2006, chapter 4). This conflicting evidence may well be a function of the realities of the decision making context in which court of appeals judges are operating. Simply put, the strategic model lacks facial validity in the context of the United States Courts of

\footnotetext{
${ }^{13}$ Epstein and Knight (2000) go so far as to characterize what they see as the shift toward strategic approaches in the study of judicial behavior as a "sea change" that is leading to a veritable revolution in the field. Hall and Brace (1999) are more guarded in their evaluation, though they, too, see the development of strategic approaches as beneficial and are cautiously optimistic about its advancement. ${ }^{14}$ Other notable works include Boucher and Segal (1995), Brenner (1982), Brenner and Krol (1989), Epstein and Knight (1998), Gely and Spiller (1990), Hammond, Bonneau, and Sheehan (2005). Of course, all of the contemporary work owes a significant intellectual debt to Murphy's puissant book, Elements of Judicial Strategy (1964).
} 
Appeals given their tremendous workloads; that is, given the fact that court of appeals jurists do not have the necessary time to engage in strategic calculations in any but the most limited of circumstances.

Further, the strategic model is narrow in its sole focus on securing preferred policy outcomes. It ignoresas does the attitudinal model —-the fact that judges care about and are influenced by their working environments and the colleagues with whom they work as well as the policy ends they seek to achieve. Of course courts of appeals judges care about policy outcomes. That is much too well established a fact to be gainsaid. But, court of appeals judges, who almost always dispose of cases in multi-judge panels, are cognizant of the identities and roles of the other judges with whom they work. Further, those identities and roles can and do matter for behavior within that group, a proposition that is supported by a small but informative body of research.

Early work by Atkins (1973), Ulmer (1971), and Walker (1973a, 1973b), among others, all profitably viewed decision making through the prism of small group theory. Common to this body of scholarship is the idea that the status of group members matters for their behavior. Some members of collegial courts are better able, by virtue of formal authority or dint of personality, to exercise leadership (e.g., Ulmer 1971). In addition, those with higher levels of status may be advantaged in terms of securing support from other members of the collegial body of which they are members (Walker 1973b).

Conversely, those with lower status (e.g., lower state court judges serving on the Washington State Supreme Court) may be deferential vis-à-vis the permanent members of the bench (e.g., regular supreme court justices) (Walker 1973a).

District court judges serving by designation are, by definition, temporary members of the small group constituted by the three-judge panel on the courts of appeals. And, as noted previously, there is reason to assume that they may see themselves (and be seen by others) as possessing a different (lower) status than the regularly sitting, active duty judges with whom they are rendering decisions. They, then, afford us an opportunity to evaluate whether and how a particular small group member-the designated district court judge-is influenced by his particular status in the group as well as his fellow panel members.

In particular, we, first, consider the extent to which the decision making of designated district court judges is influenced by their panel colleagues. Recall that some legal observers (e.g., Saphire and 
Solimine 1995) have voiced concerns that designated district court judges may be unduly deferential to the regularly sitting, active duty circuit court judges on the panel (and hence not full partners in the deliberative process). And, indeed, there is empirical evidence consistent with that contention (e.g., Brudney and Ditslear 2001; Cohen 2002; Hettinger, Lindquist, and Martinek 2006, chapter 3).

Accordingly, we should expect to see the vote choices of designated district court judges conditioned by the preferences of their panel colleagues. More formally: the more liberal [conservative] a designated district court judge, the more likely that judge is to cast a liberal [conservative] vote but the likelihood of a liberal [conservative] vote will be diminished the more conservative [liberal] the other judges on the threejudge panel.

We also assess the consistency of the voting behavior of district court judges serving by designation. As discussed previously, some students of the courts (e.g., Carrington 1969)—and even some judges (see, e.g., Cohen 2002)—have suggested that designated district court judges will introduce uncertainty in the law because of the temporary nature of their service. Considering the variance in ideological voting of designated district court judges is one means of evaluating the extent to which they are more variable in their voting behavior. Accordingly, we hypothesize as follows: designated district court judges will be positively associated with variance in ideological voting.

The empirical evidence we bring to bear below on these hypotheses will be informative both with regard to the utility of a small group perspective for understanding decision making on the United States Courts of Appeals and the debate over whether designated district court judges behave in meaningfully different ways from regular court of appeals judges.

\section{Data and Methodology}

To subject the two primary hypotheses articulated above to empirical testing, we utilize data from 1970 to 1996 available from the U.S. Court of Appeals Database (Songer 1999). Because our hypotheses are at the individual level, we transformed Songer's database such that the judge-vote is the unit of analysis, rather than the case, using a modification of the code developed by Collins (2006). Our analysis is limited to three-judge panels and, thus, we exclude en banc decisions. ${ }^{15}$ Our dependent variable

\footnotetext{
${ }^{15}$ En banc decision making also involves a small group, though it is obviously a larger small group than that represented by a three-judge panel. Our decision to exclude judge-votes from en banc proceedings
} 
indicates the ideological direction of each judge's vote, scored 1 for a liberal vote and 0 for a conservative vote. In cases involving the rights of the criminally accused, a liberal vote supports the criminal defendant, while a conservative vote is in favor of the government. In civil rights and liberties cases, a liberal vote supports the litigant alleging a violation of her civil rights or liberties, while a conservative vote is the opposite thereof. In economic cases, a liberal vote supports the interests of labor, the government, or the economic underdog, while a conservative vote is pro-business.

Since we hypothesize influences on both the mean and variance of the individual judge's votes, we employ a heteroskedastic probit model. The heteroskedastic probit model relaxes the assumption that the variance in a judge's vote is constant, and instead allows the variance to alter with respect to predictor variables. The log likelihood function for the heteroskedastic probit model is as follows:

$$
\log L=\sum_{i}\left(y_{i} \log \Phi\left(\frac{X_{i} \beta}{\exp \left(Z_{i} \gamma\right)}\right)-\left(1-y_{i}\right) \log \left[1-\Phi\left(\frac{X_{i} \beta}{\exp \left(Z_{i} \gamma\right)}\right)\right]\right)
$$

The primary distinction between the more familiar homoskedastic probit model and the heteroskedastic probit model is the inclusion of the variance model in the denominator of the heteroskedastic model (Alvarez and Brehm 1995, 1062). As such, the unrestricted (i.e., the heteroskedastic) model produces two categories of estimates: those related to the causes of liberal or conservative voting (i.e., involving the mean of the distribution of the dependent variable) and those related to the causes of consistent or inconsistent voting (i.e., involving the variance of the distribution of the dependent variable). If the error variance is constant, the model reduces to the standard, homoskedastic probit model. If, as we hypothesize, the error variance in a judge's voting behavior is non-constant, we can reject the null hypothesis of homoskedasticity and conclude that the model is systematically heteroskedastic. To control for the non-independence of observations-in that judges appear more than once in the data-we estimate the model using robust standard errors, clustered on judge (see, e.g., King 1998, 34). Further, we employ the weights reported in the U.S. Courts of Appeals Database to account for its sampling composition.

To measure each judge's Ideology, we use the scores created by Giles, Hettinger, and Peppers (2001, 2002). Based on Poole's (1998) first dimension common space scores, this variable captures the

is predicated on the fact that en bancs have unique dynamics (George 1999) and designated district court judges do not participate in them. 
dynamics of the appointment process-for both designated district court and court of appeals judges-by considering the preference of each judge's appointing president and home state senators. If senatorial courtesy is absent (i.e., the home state senators do not share the same party affiliation as the president), this variable takes on the president's common space score. If one senator from the home state delegation shares the president's party affiliation, this variable takes on that senator's ideal point score. If both of the home state senators share the party affiliation of the president, this variable takes on the mean value of the two senator's scores. To facilitate interpretation, we have rescaled this variable by adding 0.784 to each score and then multiplying the scores by 10 . This variable ranges from 0 to 14.4 , with higher scores reflecting more conservative ideologies. Accordingly, we expect that this variable will be negatively signed, indicating that judges with conservative ideologies are less likely to cast liberal votes than liberal judges.

To evaluate interpersonal influence on three-judge panels, we include a measure of Ideological Influence. For each judge serving on a panel, this variable takes on the mean Ideology score of the other two judges. We expect that this variable will be negatively signed, indicating that, the more conservative the other panelists with whom a judge is making a decision, the less likely that judge is to case a liberal vote. To investigate if district court judges are especially susceptible to this form of influence (as some critics have argued, thereby suggesting that they are not co-equal in panel deliberations), we include a District Court Judge variable in the model, scored 0 for court of appeals judges and 1 for district court judges serving on the panels by designation. We then interact this variable with our measure of Ideological Influence to determine if district court judges are distinctively influenced by their appeals court counterparts. Since we cannot infer from the sign or statistical significance of this interaction term whether district court judges are different from appeals court judges (Ai and Norton 2003), it is necessary to calculate the marginal effect and confidence intervals for this interaction term, holding all other variables at their mean or modal values. To do this, we adapt the method created by Brambor, Clark, and Golder (2006).

An important control variable in the model of vote choice (i.e., liberal or conservative vote) is litigant resources (e.g., Galanter 1974; Songer and Sheehan 1992; Songer, Sheehan, and Haire 1999). To take litigant resources into account, we include a variable in the model that captures the resource 
differential between the liberal and conservative litigant. Following Songer, Sheehan, and Haire (1999, 824), we create a status continuum of parties by ranking litigants according to increasing resource as follows: individuals $=1$, businesses $=2$, state governments $=3$, and the federal government $=4$. To compute our measure of Litigant Resources we simply subtract the conservative litigant's resource score from the liberal litigant's score. Accordingly, we expect that this variable will be positively signed, indicating that a judge is more likely to support the liberal litigant if that litigant ranks higher on the resource continuum than the conservative litigant. ${ }^{16}$

Since the courts of appeals sit below the Supreme Court in the federal judicial hierarchy, it is likewise important to control for the preferences of the Supreme Court to capture the extent to which court of appeals judges follow the ideological proclivities of their supervisory court (e.g., Benesh 2002; Haire, Lindquist, and Songer 2003; Songer, Segal, and Cameron 1994). To do this, we include a Supreme Court Ideology variable, adopted from Epstein, Martin, Segal, and Westerland (n.d.), who provide ideological surrogates for the Supreme Court on the identical metric we utilize to capture the ideologies of designated district court judges and court of appeals judges. These scores are a transformation of Martin and Quinn's (2002) ideal point estimates for the median member of the Supreme Court, mapped onto the same dimension as the Giles, Hettinger, and Peppers (2002) scores. To facilitate interpretation, we have rescaled these scores by adding 0.103 to each ideal point and multiplying them by 10 . This variable ranges from 0 to 2.89, with higher scores reflecting more conservative Supreme Courts. As such, we expect this variable will be negatively signed, indicating that, as the median justice on the Supreme Court becomes more conservative, so too will the decision making patterns of court of appeals judges (i.e., they will be less likely to vote liberally).

We also control for the issue area implicated in the case. First, judges are less likely to cast liberal votes in criminal cases because such cases are overwhelmingly legally inconsequential but must be heard due to the mandatory docket of the United States Courts of Appeals (Martinek 2006, 811). Despite their tremendous importance to the individual litigants involved, they simply do not raise important

\footnotetext{
${ }^{16}$ As an alternative to this measure, we also employed a proxy for the perceived resources of the litigant's attorneys, scored such that $1=$ pro se counsel, 2 = court appointed counsel or public defender, $3=$ private counsel, $4=$ interest group counsel, $5=$ state or local government counsel, and $6=$ federal government counsel. That variable correlates with our litigant resources variable at 0.87 , thus making the inclusion of both variables in the model inappropriate. When we use the counsel resources variable in place of the litigant resources variable, the results do not substantively differ.
} 
legal issues and are less likely to garner judicial support (see, e.g., Howard 1981, 174-175; Songer, Sheehan, and Haire 2000,114-115). Accordingly, because votes in favor of the criminally accused or convicted are defined as liberal, our expectation is that judges will vote conservatively in criminal cases. Further, some types of cases systematically depress or enhance the effect of judicial ideology on vote choice. Habeas corpus and diversity of citizenship cases are less likely to map onto the conventional liberal-conservative ideological spectrum (Songer, Sheehan, and Haire 2000, 140). Accordingly, we include a variable-Habeas/Diversity Case-that is coded 1 if the case implicates a habeas corpus petition or if the case involves diversity of citizenship, and zero otherwise, which is then interacted with the measure of judge ideology. We have no expectation with regard to the relationship between the Habeas/Diversity Case variable and the ideological direction of the judge's vote by itself but expect its interaction with ideology to be negatively signed. Conversely, cases that involve civil rights, the First Amendment, due process, and privacy are more likely to bring the ideological preferences of the judges into play. Hence, we include a variable-Civil Rights Case—that is scored 1 if the case involved any of those issues, and 0 otherwise. In this case, we have no expectation with regard to the relationship between the Civil Rights Case variable and the ideological direction of the judge's vote but expect its interaction with ideology to be positively signed.

Thus far, our focus has been on the choice of the judge to vote liberally or conservatively. In the choice model described above, we are primarily interested in whether district court judges serving by designation are any more or less influenced by the ideological preferences of their panel colleagues than regularly sitting, active duty court of appeals judges. Recall, however, that we are also interested in evaluating whether district court judges serving by designation are any more or less variable in their voting behavior than regularly sitting active duty court of appeals judges. To this end, we include four variables in the variance vector: District Court Judge, Civil Rights Case, Habeas/Diversity Case, and Criminal Case. In each case, the variable is operationalized in the same manner as for the choice model, as described above. The District Court Judge variable is the variable of substantive interest with regard to the hypothesis about the voting consistency of district court judges serving by designation. If the variance in voting is positively related to the fact that a given judge-vote is cast by a designed district court judge, then we have evidence of voting instability among such judges, which has implications for legal 
consistency. The three other variables in the variance model (Civil Rights Case, Habeas/Diversity Case, Criminal Case) are all expected to increase variance because of the variability in ideological content in each of these types of cases.

\section{Results}

\section{[Table 1 About Here]}

Table 1 reports the results from the heteroskedastic probit model that forecasts the probability of observing a judge cast a liberal vote. The model correctly predicts $66.5 \%$ of votes for a percent reduction in error of $13.7 \%$. Importantly, note that the results reveal that systematic heteroskedasticity exists in the data (though, as discussed further below, that heteroskedasticity is not related to designated district court judges). Evidence of this is provided by the heteroskedasticity test that compares the unrestricted model to the homoskedastic model by way of the likelihood ratio test, where $L_{0}$ is the log likelihood for the homoskedastic probit model, $L_{H}$ is the log likelihood for the heteroskedastic probit model, and $k$ is the number of estimated parameters in the variance portion of the model (Alvarez and Brehm 1995: 1063). The likelihood ratio is $L R=2 \times\left(L_{H}-L_{0}\right)$, which is distributed by $x^{2}$ with $k$ degrees of freedom. As this test statistic signifies, we can reject the null hypothesis of homoskedasticity, indicating that the heteroskedastic probit model provides a better fit than the restricted model. ${ }^{17}$ To facilitate interpretation, we discuss the marginal effects of each variable, which were calculated altering the variables of interest from 0 to 1 for dichotomous variables and from one standard deviation below the mean to one standard deviation above the mean for continuous variables, holding all other variables constant at their mean or modal values, as appropriate.

Turning first to the mean vector, the results provide strong—-though not surprising—support for the role of ideology in shaping decision making on the courts of appeals. Recall that we interact the Ideology variable with the Habeas/Diversity Case and with Civil Rights Case variables, hence the parameter estimate associated with this variable only reflects the change in ideology in nonhabeas/diversity cases and non-civil rights cases. In other words, this variable only reflects the effect of ideology in labor relations, economics, and miscellaneous cases. For these cases, in substantive terms, a one standard deviation change in the Ideology variable increases the likelihood of observing a liberal vote

17 This is confirmed by the use of the asymptotically equivalent Wald test statistic (Wald $x^{2}, \sigma^{2}=95.5$, significant at <.001). 
by about $5 \%$. A change from the minimum to maximum value of this variable increases the chances of observing a liberal vote by $14 \%$.

In addition to a judge's ideology, the model also provides evidence that the ideology of the other members of the panel influences judicial decision making, even when we control for the judge's own ideology. The constituent term, Ideological Influence, reports the influence of the other two panel members on a court of appeals judge (i.e., when District Court Judge $=0$ ). A one standard deviation change in the ideology of the other two panel members increases the likelihood of observing a court of appeals judge cast a liberal vote by $4.4 \%$; the minimum to maximum change in this variable increases the probability of observing a liberal vote by $11 \%$. Thus, not only does the ideology of the other panel members influence a court of appeals judge's decision making, but it also rivals a judge's own ideology as a predictor of vote choice. This is consistent with Sunstein's assertion: “Often people's judgments and behavior are nicely predicted by their own beliefs and commitments—but their judgments and behavior are often predicted even better by the beliefs and commitments of those who surround them" $(2003,166)$.

\section{[Figure 1 About Here]}

Because we cannot infer from the parameter estimates or statistical significance of the interaction term, Ideological Influence $\times$ District Court Judge, whether district court judges are especially susceptible to influence by their peers, Figure 1 plots this effect. The solid line indicates the change in the predicted probability of observing a district court judge cast a liberal vote as his or her fellow judges become more conservative, as compared to an appeals court judge. The significance levels are represented by the $95 \%$ confidence intervals drawn around this line. The marginal effect is significant whenever the upper and lower bounds of the $95 \%$ confidence intervals are both above (or below) the zero line. Figure 1 reveals two interesting findings. First, as a whole, district court judges are more liberal than their appeals court counterparts. This is evidenced by the fact that, regardless of the ideology of the other judges, the marginal effect is positive and significantly different from zero across the $X$ axis. ${ }^{18}$ Second, district court judges are far less susceptible to the influence of their fellow panelists than court of appeals jurists. For example, the minimum to maximum change in the ideology of a district court judge's fellow panelists

\footnotetext{
${ }^{18}$ Indeed, this is corroborated by the constituent variable, District Court Judge, which indicates the difference between a designated district judge and an appeals court judge when the district court judge serves on a panel in which the mean ideology of his or her fellow judges equals zero - that variable is positively signed and achieves statistical significance at the .055 level.
} 
increases the likelihood of observing the district court judge cast a liberal vote by only $2.3 \%$. As discussed above, this same change increases the chances of observing an appeals court judge cast a liberal vote by $11 \%$. Thus, there are significant differences between designated district court judges and court of appeals judges. District court judges are more liberal and they are less receptive to the influence of their fellow panelists than court of appeals judges.

This finding suggests that, contrary to conventional wisdom, designated district court judges are not all that deferential, implying that district court judges are far more solitary in their decision making processes, even when serving by designation on court of appeals panels. While this is inconsistent with the positions advanced by contemporary critics of designated district judge participation on court of appeals panels, this can nonetheless be explained by the fact that district judges are trained and socialized as singular decision makers. Conversely, court of appeals judges are far more familiar with the give-and-take that is the standard of collegial decision making and this is evidenced by the strong influence wielded by their fellow panelists. In other words, designated district judges-less familiar with the conventions of collegial decision making-vote in a type of vacuum. The implication of this is that that they are not fungible with court of appeals judges.

In addition to a judge's policy preferences, and those of the judge's fellow panelists, the ideology of the Supreme Court also influences decision making on the United States Courts of Appeals. In particular, a one standard deviation change in the ideology of the median justice on the Supreme Court in the liberal direction increases the probability of observing a liberal vote by about $4 \%$. The minimum to maximum change in this variable increases the likelihood of a liberal vote by $7 \%$. Thus, all things being equal, we can expect to observe modest changes in the voting behavior of judges serving on three-judge panels as the ideology of the median member of the Supreme Court changes. Moreover, the results provide support for the important role of litigant resources in shaping decision making in the courts of appeals. When the liberal litigant faces a conservative litigant one step below the resource continuum reported above, a $5 \%$ increase in the likelihood of observing a liberal vote results. For example, when the federal government argues the liberal position against a conservative business, the likelihood of observing a liberal vote increases by almost $20 \%$ compared to a scenario in which a conservative state squares off against a liberal individual. 


\section{[Figure 2 About Here]}

The results regarding the issue area controls are also of import. First, the model reveals that judges are significantly less likely to cast liberal votes in criminal rights cases. Compared to other issue areas, a judge is $23 \%$ more likely to vote conservatively in criminal cases, likely due to the tendency for many of these cases to involve relatively frivolous appeals. Figure 2 plots the judge's predicted voting behavior in civil rights (top of Figure 2) and habeas corpus/diversity cases (bottom of Figure 2). Considering, first, civil rights cases, this figure reveals that judges tend to vote about $10 \%$ more liberally in civil rights cases than in other issue areas. However, this difference is only significant for liberal, moderate, and moderately conservative judges. For judges with extremely conservative credentials, their decision making does not differ in civil rights cases. The results of the figure that plots the judges' decision making in habeas corpus and diversity of citizenship cases (i.e., the bottom of Figure 2) reveals almost identical results: in these cases, judges are about $14 \%$ more likely to cast liberal votes, and this finding holds regardless of a judge's ideological preferences.

Turning now the variables in the variance vector, two important findings emerge. First, district court judges are not more variable than their court of appeals counterparts. Thus, while district court judges are more liberal, and less susceptible to the influence of their fellow panelists, their decision making is neither more nor less consistent than that of the regularly sitting, active duty circuit court judges. Second, the results of the issue area controls reveal that judges' voting behavior is less consistent in criminal, civil rights, habeas corpus, and diversity of citizenship cases. This comports with the results in the mean model. That is, not only are judges more likely to modify their behavior in these types of cases, but these alterations systematically affect the extent to which we can anticipate consistent decision making. For example, the results regarding the Criminal Case variable reveal that judges are more conservative in these cases (choice model) and that this influences the error variance associated with their choices (variance model). That is, all judges-liberal, moderate, and conservative-are more conservative than we would normally expect in criminal cases.

\section{Conclusion and Discussion}

In this paper, we set out to simultaneously examine an empirical question with important public policy implications and suggest a profitable direction for theory building vis-à-vis judicial behavior. 
Designated district court judges have become integral to the decision making process in the United States Courts of Appeals. The ever increasing workloads faced by these major intermediate appellate courts in the federal system (Administrative Office of the United States Courts various years, Table S-1; Songer, Sheehan, and Haire 2000, 14-15), coupled with increasingly lengthy vacancies on the lower federal bench (Citizens for Independent Courts 2000; Massie, Hansford, and Songer 2004; Nixon and Goss 2001), mean that the courts of appeals have had to develop new strategies to meet their obligations. The use of designated district court judges is one such strategy. ${ }^{19}$ Some judges, legal observers, and academics, however, have not viewed the increasing use of this strategy with sanguinity. They have raised concerns that such judges may, among other things, threaten the appellate process by being too deferential to the court of appeals judges with whom they work and compromise the consistency of the law due to their status as outsiders on the court. The evidence we offer in this paper, however, should offer some comfort to those concerned about the use of designated district court judges. In terms of the influence of their fellow panelists on their own votes, designated district court judges are, if anything, less likely to be influenced by their colleagues. In terms of the consistency of their behavior, designated district court judges are no more or less likely to demonstrate inconsistency in their voting behavior than the court of appeals judges with whom they render decisions.

To be sure, ideological voting and variance in ideological voting are not the only phenomena of interest when it comes to the participation of district court judges. For example, researchers have established that permanent newcomers to the bench (i.e., new court of appeals judges) evidence a reluctance to file separate opinions (Hettinger, Lindquist, and Martinek 2003). The same may be true for designated judges, who are temporary newcomers to the bench. Brudney and Ditslear's (2001) analysis of cases involving National Labor Relations Act claims suggests, in fact, that this is true. Other scholars have demonstrated that "freshmen" on the United States Supreme Court are more likely to conform to precedent, an effect that tapers off as the justices' tenure in office progresses (Hurwitz and Stefko 2004). It is not unreasonable to suppose that the same may hold true of designated district court judges. Of special interest in this regard would be whether designated district court judges are equally attentive to

\footnotetext{
${ }^{19}$ Other strategies include reducing the number of cases granted oral argument (Chapper 1983), limiting opinion publication (Dragich 1995; Wasby 2004), and increased use of staff attorneys for case screening (Haire and Lindquist 1997).
} 
both circuit law and Supreme Court precedent. Further, in addition to any behavioral differences between designated district court judges and regular circuit court judges, there may well be consequences for the legitimacy of the courts (Cohen 2002; Saphire and Solimine 1995).

The analysis that we have presented in this paper also speaks to the usefulness of taking a small group perspective to theory building in the study of judicial behavior. The key finding in this regard is not, as we had anticipated, a special sensitivity of designated district court judges to the preferences of their circuit judge colleagues on a panel. But, our finding that the ideology of fellow panelists matters for the decisions rendered by regular circuit court judges indicates that context (read: the small group context) matters. 
Table 1. Heteroskedastic Probit Model of Voting on the U.S. COURTS OF APPEALS

\begin{tabular}{ll}
\hline Predictor & $\begin{array}{l}\text { Parameter } \\
\text { Estimate }\end{array}$ \\
\hline \multicolumn{1}{c}{ CHOICE MODEL } \\
Ideology & \\
Ideological Influence & $-.024(.005)^{\star * *}$ \\
District Court Judge & $-.021(.006)^{\star * *}$ \\
Ideological Influence $\times$ District Court Judge & $.223(.140)$ \\
Litigant Resources & $-.050(.023)^{\star}$ \\
Supreme Court Ideology & $.124(.008)^{\star * *}$ \\
Civil Rights Case & $-.062(.021)^{\star *}$ \\
Ideology $\times$ Civil Rights Case & $.165(.184)$ \\
Habeas/Diversity Case & $-.058(.030)^{\star *}$ \\
Ideology $\times$ Habeas/Diversity Case & $-.233(.196)$ \\
Criminal Case & $-.033(.024)$ \\
Constant & $-1.64(.503)^{\star \star *}$ \\
& $.455(.065)^{\star * *}$
\end{tabular}

VARIANCE MODEL

District Court Judge

$.047(.082)$

Civil Rights Case

$.968(.253)^{* \star *}$

Habeas/Diversity Case

$.560(.105)^{\star * *}$

Criminal Case

$.814(.248)^{\star \star *}$

\section{MOdEL Diagnostics}

N

18,754

Wald $\chi^{2}$

$533.96^{\star * *}$

Heteroskedasticity Test $\left(\chi_{d f=4}^{2}\right)$

$2,803.5^{\star * *}$

$\%$ Correctly Predicted

66.5

\% Reduction in Error

13.7

Dependent variable indicates the ideological direction of the individual judge's vote $(1=$ liberal, $0=$ conservative). Numbers in parentheses indicate robust standard errors, clustered on judge. ${ }^{*} p \leq .05$; ${ }^{* *} p \leq .01$; ${ }^{* * *} p \leq .001$ (one-tailed tests). 
Figure 1. The MARginAL EFFECT OF IDEOLOGICAL INFLUENCE ON Designated District Court Judges

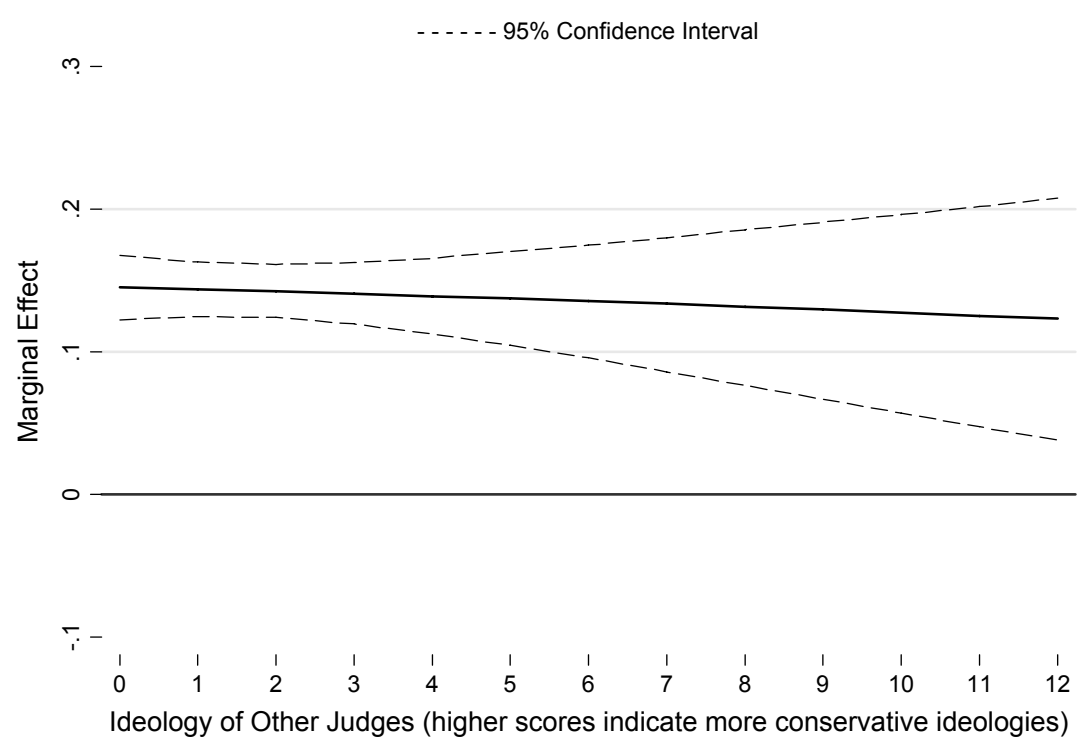


Figure 2. The Marginal EfFect of IDEOLogy in Civil Rights and Habeas Corpus and Diversity of Citizenship CaSes

Civil Rights Cases

- . - . 95\% Confidence Interval

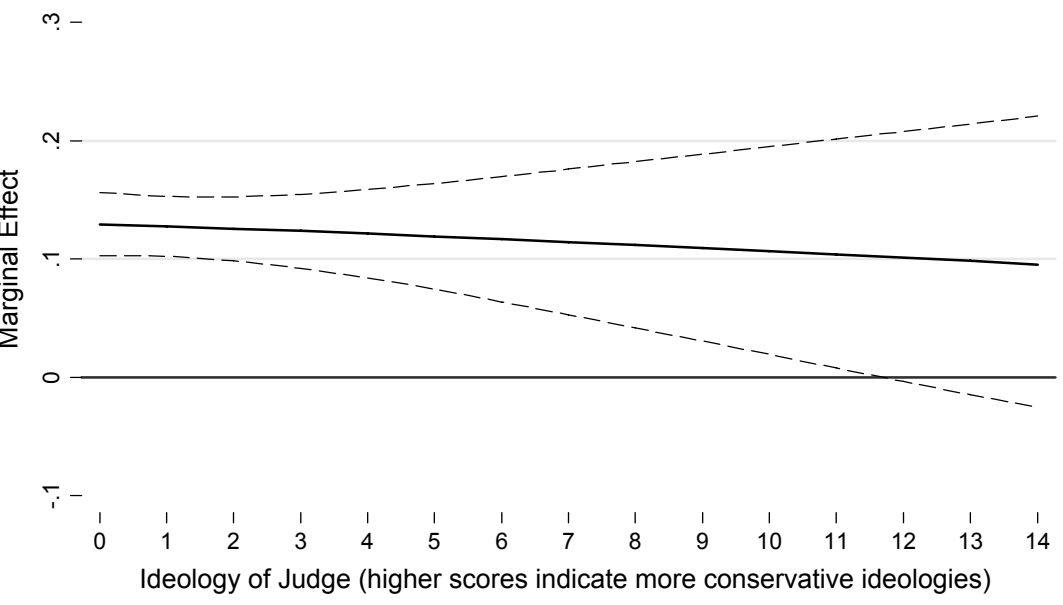

Habeas Corpus and Diversity of Citizenship Cases

- . - . 95\% Confidence Interval

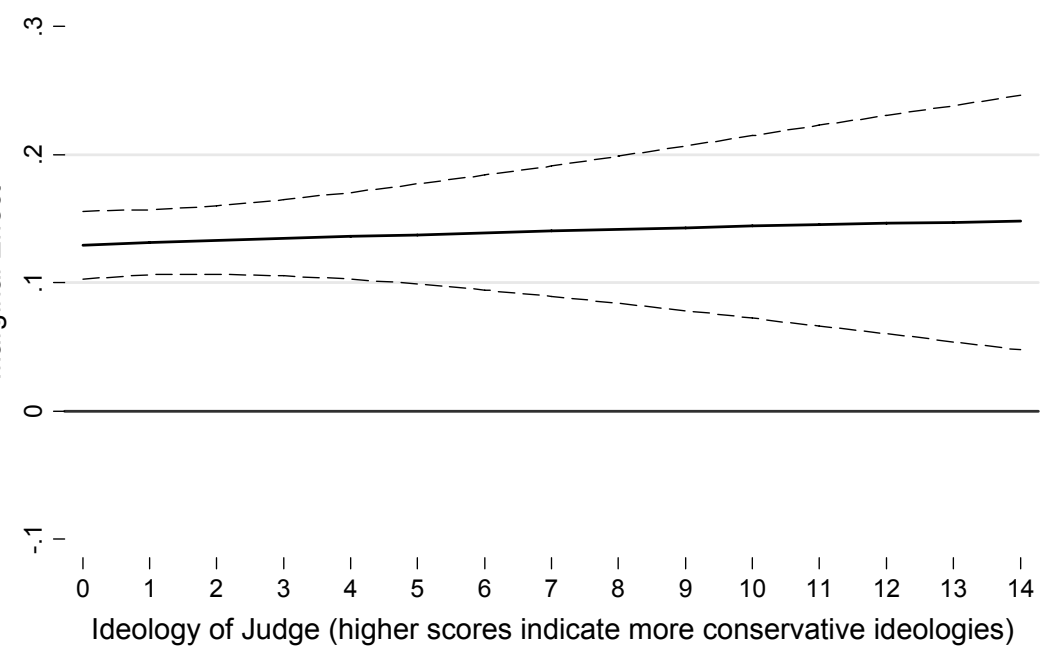




\section{References}

Administrative Office of the United States Courts. Various years. Judicial Business of the United States Courts: Annual Report of the Director. Washington, D.C.: U.S. Government Printing Office.

Ai, Chunrong, and Edward C. Norton. 2003. "Interaction Terms in Logit and Probit Models." Economics Letters 80(1): 23-129.

Alexander, A. Lamar, Jr. 1965. "En Banc Hearings in the Federal Courts of Appeals: Accommodating Institutional Responsibilities." New York University Law Review 40(Spring): 563-608.

Alvarez, R. Michael, and John Brehm. 1995. "American Ambivalence towards Abortion Policy: Development of a Heteroskedastic Probit Model of Competing Values." American Journal of Political Science 39(4): 1055-1082.

Atkins, Burton M. 1973. "Judicial Behavior and Tendencies toward Conformity in a Three Member Small Group: A Case Study of Dissent Behavior on the U.S. Courts of Appeals." Social Science Quarterly 54(1): 41-53.

Atkins, Burton M. and William Zavoina. 1974. "Judicial Leadership on the Court of Appeals: A Probability Analysis of Panel Assignment in Race Relations Cases on the Fifth Circuit." American Journal of Political Science 18(4): 701-711.

Bell, Lauren Cohen. 2002. Warring Factions: Interest Groups, Money, and the New Politics of Senate Confirmation. Columbus: Ohio State University Press.

Benesh, Sara C. 2002. The U.S. Court of Appeals and the Law of Confessions: Perspectives on the Hierarchy of Justice. New York: LFB Scholarly Publishing.

Berelson, Bernard R., Paul F. Lazarsfeld, and William N. McPhee. 1954. Voting: A Study of Opinion Formation in a Presidential Campaign. Chicago: University of Chicago Press.

Boucher, Robert L., Jr., and Jeffrey A. Segal. 1995. "Supreme Court Justices as Strategic Decision Makers: Aggressive Grants and Defensive Denials on the Vinson Court." Journal of Politics 57(3): 824-837.

Brace, Paul and Melinda Gann Hall. 1990. "Neo-Institutionalism and Dissent in State Supreme Courts." Journal of Politics 52(1): 54-69.

Brace, Paul and Melinda Gann Hall. 1995. "Studying Courts Comparatively: The View from the American States." Political Research Quarterly 48(1): 5-29.

Brace, Paul and Melinda Gann Hall. 1997. "The Interplay of Preferences, Case Facts, Context, and Rules in the Politics of Judicial Choice." Journal of Politics 59(4): 1206-1231.

Brambor, Thomas, William R. Clark, and Matt Golder. 2006. "Understanding Interaction Models: Improving Empirical Analyses." Political Analysis 14(1): 63-82.

Bratton, Kathleen A. and Kerry L. Haynie. 1999. "Agenda Setting and Legislative Success in State Legislatures: The Effects of Gender and Race." Journal of Politics 61(3): 658-679.

Brenner, Saul. 1982. "Strategic Choice and Opinion Assignment on the U.S. Supreme Court: A Reexamination.” Western Political Quarterly 35(2): 204-211.

Brenner, Saul and John F. Krol. 1989. "Strategies in Certiorari Voting on the United States Supreme Court." Journal of Politics 51(3): 828-840.

Brown, J. Robert, Jr., and Allison Herren Lee. 2000. "Neutral Assignment of Judges at the Court of Appeals." Texas Law Review 78(April): 1037-1115.

Brudney, James J. and Corey Ditslear. 2001. "Designated Diffidence: District Court Judges on the Courts of Appeals." Law \& Society Review 35(3): 565-606.

Caldeira, Gregory A., John A. Clark, and Samuel C. Patterson. 1993. "Political Respect in the Legislature." Legislative Studies Quarterly 18(1): 3-28.

Caldeira, Gregory A. and Samuel C. Patterson. 1987. "Political Friendship in the Legislature." Journal of Politics 49(4): 953-975.

Campbell, Angus, Philip E. Converse, Warren E. Miller, and Donald E. Stokes. 1960. The American Voter. Chicago: University of Chicago Press.

Carp, Robert A. and C.K. Rowland. 1983. Policymaking and Politics in the Federal District Courts. Knoxville: University of Tennessee Press.

Carrington, Paul. 1969. "Crowded Dockets and the Courts of Appeals: The Threat to the Function of Review and the National Law." Harvard Law Review 82(Spring): 542-617.

Chapper, Joy A. 1986. "Oral Argument and Expediting Appeals: A Compatible Combination." University of Michigan Journal of Law Reform 16(Spring): 517-526. 
Citizens for Independent Courts. 2000. Uncertain Justice: Politics and America's Courts. New York: Century Foundation Press.

Cohen, Jonathan Matthew Cohen. 2002. Inside Appellate Courts: The Impact of Court Organization on Judicial Decision Making in the United States Courts of Appeals. Ann Arbor: University of Michigan Press.

Collins, Paul M., Jr. 2006. "Transforming the Original U.S. Supreme Court Judicial Database: An Alternative Approach for Use with Stata." Law and Courts 16(1): 22-24.

Coons, John E. 1987. "Consistency." California Law Review 75(January): 59-113.

Cross, Frank B. and Emerson H. Tiller. 1998. "Judicial Partisanship and Obedience to Legal Doctrine: Whistleblowing on the Federal Courts of Appeals." Yale Law Journal 107(7): 2155-2176.

Danelski, David J. [1960] 1989. "The Influence of the Chief Justice in the Decisional Process of the Supreme Court." In American Court Systems, ed. Sheldon Goldman and Austin Sarat. New York: Longman.

Dragich, Martha J. 1995. "Will the Federal Courts of Appeals Perish if They Publish? Or Does the Declining Use of Opinions to Explain and Justify Judicial Decisions Pose a Greater Threat?" American University Law Review 44(February): 757-802.

Drahozal, Christopher R. 1998. "Judicial Incentives and the Appeals Process." Southern Methodist Law Review 51(1): 469-503.

Epstein, Lee and Jack Knight. 1998. The Choices Justices Make. Washington, D.C.: CQ Press.

Epstein, Lee and Jack Knight. 2000. "Toward a Strategic Revolution in Judicial Politics: A Look Back, A Look Ahead." Political Research Quarterly 53(3): 625-661.

Epstein, Lee, Andrew D. Martin, Jeffrey A. Segal, and Chad Westerland. N.d. "The Judicial Common Space." Journal of Law, Economics, and Organization. Forthcoming.

Feinberg, Wilfred. 1984. "the Office of Chief Judge of a Federal Court of Appeals." Fordham Law Review 53(December): 369-389.

Galanter, Marc. 1974. "Why the 'Haves' Come Out Ahead: Speculations on the Limits of Legal Change." Law and Society Review 9(1): 95-160.

Gely, Rafael and Pablo T. Spiller. 1990. "A Rational Choice Theory of Supreme Court Statutory Decisions with Application to the State Farm and Grove City Cases." Journal of Law, Economics and Organization 6(2): 263-300.

George, Tracey E. 1999. "The Dynamics and Determinants of the Decision to Grant En Banc Review." Washington Law Review 74(1): 213-274.

Giles, Michael W., Virginia A. Hettinger, and Todd Peppers. 2001. "Picking Federal Judges: A Note on Policy and Partisan Selection Agendas." Political Research Quarterly 54(3): 623-641.

Giles, Michael W., Virginia A. Hettinger, and Todd Peppers. 2002. "Measuring the Preferences of Federal Judges: Alternatives to Party of the Appointing President." Emory University. Typescript.

Goldman, Sheldon. 1966. "Voting Behavior on the United States Courts of Appeals, 1961-1964." American Political Science Review 60(2): 374-383.

Goldman, Sheldon. 1975. "Voting Behavior on the U.S. Courts of Appeals Revisited." American Political Science Review 69(2): 491-506.

Green, Justin J. and Burton M. Atkins. 1978. "Designated Judges: How Well Do They Perform?" Judicature 61(8): 358-370.

Haire, Susan B. and Stefanie A. Lindquist. 1997. "An Agency and Twelve Courts: Social Security Disability Cases in the U.S. Courts of Appeals." Judicature 80(2): 230-236.

Haire, Susan B., Stefanie A. Lindquist, and Donald R. Songer. 2003. "Appellate Court Supervision in the Federal Judiciary: A Hierarchical Perspective." Law \& Society Review 37(1): 143-168.

Hall, Melinda Gann. 1992. "Electoral Politics and Strategic Voting in State Supreme Courts." Journal of Politics 54(2): 427-446.

Hall, Melinda Gann and Paul Brace. 1992. "Toward an Integrated Model of Judicial Voting Behavior." American Politics Quarterly 20(2): 147-168.

Hall, Melinda Gann and Paul Brace. 1996. "Justices' Responses to Case Facts: An Interactive Model." American Politics Quarterly 24(2): 237-261.

Hall, Melinda Gann and Paul Brace. 1999. "State Supreme Courts and Their Environments: Avenues to General Theories of Judicial Choice." In Supreme Court Decision-Making: New Institutionalist Approaches, ed. Cornell W. Clayton and Howard Gillman. Chicago: University of Chicago Press. 
Hammond, Thomas H., Chris W. Bonneau, and Reginald S. Sheehan. 2005. Strategic Behavior and Policy Choice on the U.S. Supreme Court. Stanford: Stanford University Press.

Hare, A. Paul, Edgar F. Borgatta, and Robert F. Bales, eds. 1965. Small Groups: Studies in Social Interaction. Revised edition. New York: Alfred A. Knopf.

Hettinger, Virginia A., Stefanie A. Lindquist, and Wendy L. Martinek. 2003. "Acclimation Effects and Separate Opinion Writing in the U.S. Courts of Appeals." Social Science Quarterly 84(4): 792810.

Hettinger, Virginia A., Stefanie A. Lindquist, and Wendy L. Martinek. 2004. "Comparing Attitudinal and Strategic Accounts of Dissenting Behavior on the U.S. Courts of Appeals." American Journal of Political Science 48(1): 123-137.

Hettinger, Virginia A., Stefanie A. Lindquist, and Wendy L. Martinek. 2006. Judging on a Collegial Court: Influences on Federal Appellate Decision Making. Charlottesville: University of Virginia Press.

Howard, J. Woodford, Jr. 1981. Courts of Appeals in the Federal Judicial System: A Study of the Second, Fifth, and District of Columbia Circuits. Princeton: Princeton University Press.

Huckfeldt, Robert. 1979. "Political Participation and the Neighborhood Social Context." American Journal of Political Science 23(3): 579-592.

Hurwitz, Mark S. and Joseph V. Stefko. 2004. "Acclimation and Attitudes: 'Newcomer' Justices and Precedent Conformance on the Supreme Court." Political Research Quarterly 57(1): 121-129.

King, Gary. 1998. Unifying Political Methodology: The Likelihood Theory of Statistical Inference. Ann Arbor, MI: The University of Michigan Press.

Langer, Laura. 2002. Judicial Review in State Supreme Courts: A Comparative Study. Albany: State University of New York Press.

Maltzman, Forrest, James F. Spriggs II, and Paul J. Wahlbeck. 2000. Crafting Law on the Supreme Court: The Collegial Game. New York: Cambridge University Press.

Mansbridge, Jane. 1999. "Should Blacks Represent Blacks and Women Represent Women? A Contingent 'Yes."' Journal of Politics 61(3): 628-657.

Martin, Andrew D. and Kevin M. Quinn. 2002. "Dynamic Ideal Point Estimation via Markov Chain Monte Carlo for the U.S. Supreme Court, 1953-1999." Political Analysis 10(2): 134-153.

Martinek, Wendy L. 2006. "Small Group Theory and the United States Courts of Appeals." Paper presented at the annual meeting of the Midwest Political Science Association.

Massie, Tajuana, Thomas G. Hansford, and Donald R. Songer. 2004. "The Timing of Presidential Nominations to the Lower Federal Courts." Political Research Quarterly 57(1): 145-154.

Murphy, Walter F. 1964. Elements of Judicial Strategy. Chicago: University of Chicago Press.

Murphy, Walter F. 1966. "Courts as Small Groups." Harvard Law Review 79(8): 1565-1572.

Nixon, David C. and David L. Goss. 2001. "Confirmation Delay for Vacancies on the Circuit Courts of Appeals." American Politics Research 29(1): 246-274.

Note. 1963. "The Second Circuit: Federal Judicial Administration in Microcosm." Columbia Law Review 63(5): 574-908.

Ostberg, C.L. and Matthew E. Wetstein. 2004. "Equality Cases and the Attitudinal Model in the Supreme Court of Canada." Paper presented at the annual meeting of the Canadian Political Science Association, Winnipeg, Manitoba.

Peters, Christopher J. 1996. "Foolish Consistency: On Equality, Integrity, and Justice in Stare Decisis." Yale Law Journal 105(June): 2031-2115.

Poole, Keith T. 1998. "Recovering a Basic Space from a Set of Issue Scales." American Journal of Political Science 42(3): 954-993.

Ringquist, Evan J. and Craig E. Emmert. 1999. "Judicial Policymaking in Published and Unpublished Decisions: The Case of Environmental Civil Litigation." Political Research Quarterly 52(1): 7-37.

Robertson, Roby D. 1980. "Small Group Decision Making: the Uncertain Role of Information in Reducing Uncertainty." Political Behavior 2(2): 163-188.

Rowland, C.K. and Robert A. Carp. 1980. "A Longitudinal Study of Party Effects on Federal District Court Propensities." American Journal of Political Science 24(2): 291-305.

Rowland, C.K. and Robert A. Carp. 1983. "The Relative Effects of Maturation, Time Period, and Appointing President on District Judges' Policy Choices: A Cohort Analysis." Political Behavior 5(1): 109-133.

Rowland, C.K. and Robert A. Carp. 1996. Politics and Judgment in Federal District Courts. Lawrence: University of Kansas Press. 
Saphire, Richard B. and Michael E. Solimine. 1995. "Diluting Justice on Appeal?: An Examination of the Use of District Court Judges Sitting by Designation on the United States Courts of Appeals." University of Michigan Journal of Law Reform 28(2): 351-407.

Scherer, Nancy. 2005. Scoring Points: Politicians, Activists, and the Lower Federal Court Appointment Process. Stanford: Stanford University Press.

Schick, Marvin. 1970. Learned Hand's Court. Baltimore: Johns Hopkins Press.

Segal, Jeffrey A. and Harold J. Spaeth. 1993. The Supreme Court and the Attitudinal Model. New York: Cambridge University Press.

Segal, Jeffrey A. and Harold J. Spaeth. 2002. The Supreme Court and the Attitudinal Model Revisited. New York: Cambridge University Press.

Shavell, Steven. 1995. "The Appeals Process as a Means of Error Correction." Journal of Legal Studies 24(June): 379-426.

Shavell, Steven. 2006. "The Appeals Process and Adjudicator Incentives." Journal of Legal Studies 35(January): 1-29.

Solimine, Michael E. 1988. "Ideology and En Banc Review." North Carolina Law Review 67(1): 29-76.

Songer, Donald R. 1998. United States Courts of Appeals Database Phase 1, 1925-1996. Columbia, SC: Department of Political Science, University of South Carolina. Available at http://www.as.uky.edu/polisci/ulmerproject/appctdata.htm.

Songer, Donald R. and Susan B. Haire. 1992. "Integrating Alternative Approaches to the Study of Judicial Voting: Obscenity Cases in the U.S. Courts of Appeals." American Journal of Political Science 36(4): 963-982.

Songer, Donald R., Jeffrey A. Segal, and Charles M. Cameron. 1994. "The Hierarchy of Justice: Testing a Principal-Agent Model of Supreme Court-Circuit Court Interactions." American Journal of Political Science 38(3): 673-696.

Songer, Donald R. and Reginald S. Sheehan. 1992. "Who Wins on Appeal? Upperdogs and Underdogs in the United States Courts of Appeals." American Journal of Political Science 36(1): 235-258.

Songer, Donald R., Reginald S. Sheehan, and Susan B. Haire. 1999. "Do the 'Haves' Come out Ahead over Time? Applying Galanter's Framework to Decisions of the U.S. Courts of Appeals, 19251988." Law \& Society Review 33(4): 811-832.

Songer, Donald R., Reginald S. Sheehan, and Susan B. Haire. 2000. Continuity and Change on the United States Courts of Appeals. Ann Arbor: University of Michigan Press.

Spriggs II, James F., Forrest Maltzman, and Paul J. Wahlbeck. 1999. "Bargaining on the U.S. Supreme Court: Justices' Responses to Majority Opinion Drafts." Journal of Politics 61(2): 485-506.

Sullivan, J. Thomas. 2002. "Justice White's Principled Passion for Consistency." Journal of Appellate Practice and Process 4(Spring): 79-87.

Sunstein, Cass R. 2003. Why Societies Need Dissent. Cambridge: Harvard University Press.

Ulmer, S. Sidney. 1971. Courts as Small and Not So Small Groups. New York: General Learning Books.

Van Winkle, Steven R. 1997. "Dissent as a Signal: Evidence from the U.S. Courts of Appeals." Paper presented at the annual meeting of the American Political Science Association.

Verba, Sidney. 1961. Small Groups and Political Behavior: A Study of Leadership. Princeton: Princeton University Press.

Wahlbeck, Paul J., James F. Spriggs II and Forrest Maltzman. 1998. "Marshalling the Court: Bargaining and Accommodation on the United States Supreme Court." American Journal of Political Science 42(1): 294-315.

Wahlbeck, Paul J., James F. Spriggs II and Forrest Maltzman. 1999. "The Politics of Dissents and Concurrences on the U.S. Supreme Court." American Politics Quarterly 27(4): 488-514.

Walker, Thomas G. 1973a. "Behavior of Temporary Members in Small Groups." Journal of Applied Psychology 58(1): 144-146.

Walker, Thomas G. 1973b. "Behavioral Tendencies in the Three-Judge District Court." American Journal of Political Science 17(2): 407-413.

Wasby, Stephen L. 1980-1981. "'Extra' Judges in a Federal Appellate Court: The Ninth Circuit." Law \& Society Review 15(2): 369-384.

Wasby, Stephen L. 2004. "Unpublished Court of Appeals Decisions: A Hard Look at the Process." Law \& : Southern California Interdisciplinary Law Journal 14(1): 67-124.

Wrightsman, Lawrence S. 1999. Judicial Decision Making: Is Psychology Relevant? New York: Kluwer Academic. 
Wrightsman, Lawrence S. 2006. The Psychology of the Supreme Court. New York: Oxford University Press. 